\title{
Synergistic use of plant-prokaryote comparative genomics for functional annotations
}

Svetlana Gerdes ${ }^{1,2}$, Basma El Yacoubi ${ }^{2}$, Marc Bailly ${ }^{2+}$, lan K Blaby ${ }^{2 \dagger}$, Crysten E Blaby-Haas ${ }^{2 \dagger}$, Linda Jeanguenin ${ }^{3 \dagger}$, Aurora Lara-Núñez ${ }^{3+}$, Anne Pribat ${ }^{3 \dagger}$, Jeffrey C Waller ${ }^{3+}$, Andreas Wilke ${ }^{4}$, Ross Overbeek ${ }^{1}$, Andrew D Hanson ${ }^{3 *}$, Valérie de Crécy-Lagard ${ }^{2 *}$

\begin{abstract}
Background: Identifying functions for all gene products in all sequenced organisms is a central challenge of the post-genomic era. However, at least 30-50\% of the proteins encoded by any given genome are of unknown or vaguely known function, and a large number are wrongly annotated. Many of these 'unknown' proteins are common to prokaryotes and plants. We set out to predict and experimentally test the functions of such proteins. Our approach to functional prediction integrates comparative genomics based mainly on microbial genomes with functional genomic data from model microorganisms and post-genomic data from plants. This approach bridges the gap between automated homology-based annotations and the classical gene discovery efforts of experimentalists, and is more powerful than purely computational approaches to identifying gene-function associations.

Results: Among Arabidopsis genes, we focused on those (2,325 in total) that (i) are unique or belong to families with no more than three members, (ii) occur in prokaryotes, and (iii) have unknown or poorly known functions. Computer-assisted selection of promising targets for deeper analysis was based on homology-independent characteristics associated in the SEED database with the prokaryotic members of each family. In-depth comparative genomic analysis was performed for 360 top candidate families. From this pool, 78 families were connected to general areas of metabolism and, of these families, specific functional predictions were made for 41 . Twenty-one predicted functions have been experimentally tested or are currently under investigation by our group in at least one prokaryotic organism (nine of them have been validated, four invalidated, and eight are in progress). Ten additional predictions have been independently validated by other groups. Discovering the function of very widespread but hitherto enigmatic proteins such as the YrdC or YgfZ families illustrates the power of our approach.

Conclusions: Our approach correctly predicted functions for 19 uncharacterized protein families from plants and prokaryotes; none of these functions had previously been correctly predicted by computational methods. The resulting annotations could be propagated with confidence to over six thousand homologous proteins encoded in over 900 bacterial, archaeal, and eukaryotic genomes currently available in public databases.
\end{abstract}

\footnotetext{
*Correspondence: adha@mail.ifas.ufl.edu; vcrecy@ufl.edu

† Contributed equally

${ }^{2}$ Department of Microbiology and Cell Science, University of Florida,

Gainesville, FL, USA

${ }^{3}$ Department of Horticultural Sciences, University of Florida, Gainesville, FL,

USA

Full list of author information is available at the end of the article
} 


\section{Background}

Accurate characterization of as many genes as possible is a central challenge of the post-genomic era and an essential precondition for progress in systems biology [1]. But this characterization is very far from completion. By various estimates, at least $30-50 \%$ of the genes of any given organism are of unknown function [2], incorrectly annotated [3,4], or have only a generic annotation such as 'ATPase' [5]. This problem is particularly acute for eukaryotic genomes, which are in general less well annotated than prokaryotic ones [6,7].

Moreover, with more than 6,000 genomes now (August 2010) in the pipeline, 1,354 of them eukaryotic (http://www.genomesonline.org), the numbers of unknown genes continue to increase [8] and annotation errors continue to increase even faster [9]. For some gene families up to $60 \%$ of the annotations are wrong [9]. Without specific functional annotation efforts, present and future genome information will become ever more corrupt and hard to analyze, and will thus be greatly underexploited.

The first step in linking gene to function is to define what constitutes a function, and this is not trivial. Full definition of a protein's function requires a combination of two features or 'dimensions': (i) a molecular function (e.g. an enzymatic activity) and (ii) a functional context (e.g. a pathway) comprising other proteins involved in the same process. Currently most annotations in public archives convey only molecular functions, mainly assigned by homology. However, when an enzymatic activity has been annotated in this way, it may well be wrong if other genes of the same pathway are not in the genome [10]. To decide whether a protein has a truly known function, it is therefore essential to take into account both the molecular and functional context dimensions. Most automated annotation platforms use only the molecular function, but when metabolic reconstruction (i.e. pathway context) is included in the annotation process this greatly improves annotation quality [11-13].

We and others have previously emphasized the power of cross-kingdom comparative genomics approaches to link gene and function $[8,14]$. This strategy was applied in the work presented here to families of unknown function shared by Arabidopsis thaliana and prokaryotes. Using the series of sieves summarized in Fig. 1, we combined comparative genomic and experimental validation approaches to discover the function of 'unknowns'. Throughout this work, our primary comparative genomics platform was the SEED database and its tools [10]; the SEED is publicly available at http://www.theseed. org/Papers/20101120/.

\section{Results and discussion}

Selecting candidate hypothetical genes families conserved in plants and prokaryotes

\section{Generation of the starting Arabidopsis gene set}

The full set of 26,207 Arabidopsis genes was extracted from the re-annotated genome [15]. To predict functions for 'unknown' genes conserved among prokaryotes and plants, it is important to avoid large gene families because their members often have different functions. The Tribe [16] and TIGR [17] algorithms were therefore used to filter out genes belonging to families having four or more members in Arabidopsis, leaving 9,250 genes corresponding to 6,034 gene families (Table 1; personal communication, Dr. Brian Haas, The Institute for Genomic Research).

\section{Selecting gene families conserved between plants and prokaryotes}

A second filter was applied to the 9,250 genes to retain those whose products have prokaryotic homologs. BLASTP [18] searches were performed in summer 2008 against the approximately 650 complete or almost complete microbial genomes then available in the SEED database. The probability threshold (E value) of better than $10^{-10}$ was imposed to ensure sufficient functional conservation between amino acid sequences included in the analysis $[19,20]$. Approximately one quarter of the 9,250 Arabidopsis genes tested were found to be similar to at least one prokaryotic gene (2,325 total, Supplemental Tables 1A, 1B, and 1C). Prokaryotic homologs for additional Arabidopsis genes would most probably be detected were this comparison to be repeated with the more numerous $(\sim 1,000)$ and more diverse microbial genomes now available.

Selecting hypothetical Arabidopsis/prokaryotic gene families Several strategies were combined to extract from the set of 2,325 conserved Arabidopsis genes those whose functions are unknown or poorly known. The following sources of evidence (available as of summer 2008) were considered: (i) Arabidopsis gene annotations in the TAIR database [21]; (ii) SEED annotations of prokaryotic orthologs of Arabidopsis genes; (iii) the list of Arabidopsis proteins of unknown function (PUFs) [22] (http://bioweb.ucr.edu/scripts/unknownsDisplay.pl); and (iv) publications in PubMed and TAIR databases (or the absence thereof).

We relied mainly on the second of these sources, i.e. SEED annotations of prokaryotic orthologs of the candidate Arabidopsis genes. The nontrivial task of establishing gene orthology is greatly aided in SEED by the subsystem-based organization of annotations (described in Methods; $[10,23])$. We considered Arabidopsis genes to be 'known' and excluded them from further analysis if they or any of their prokaryotic orthologs were 


\section{In silico phase 1: Semi-automatic}

Selected 9,250 Arabidopsis genes (in 6,034 paralogous families of 3 members or less) 2,325 of these have homologs in prokaryotes (better than $\mathrm{e}^{-10}$ )

In silico phase 2: Semi-automatic analysis of prokaryotic homologs in SEED

360 gene families shared between Arabidopsis and prokaryotes chosen because of unknown function and potentially informative contextual clues for functional prediction

\section{In silico phase 3: Manual}

Arabidopsis \& other plants
DB analysis
Expression array data
Targeting predictions
Organelle proteomics
EST abundance analysis

Prokaryotes DB analysis Gene clustering Protein fusion Interaction data sets Essentiality data Expression arrays
Protein DB analysis

Domains

Structural genomics

Fold prediction

Motifs

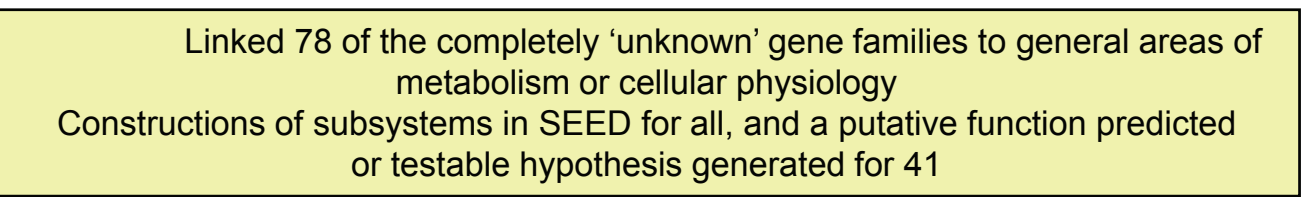

Experimental phase 4: Validation in model prokaryotes

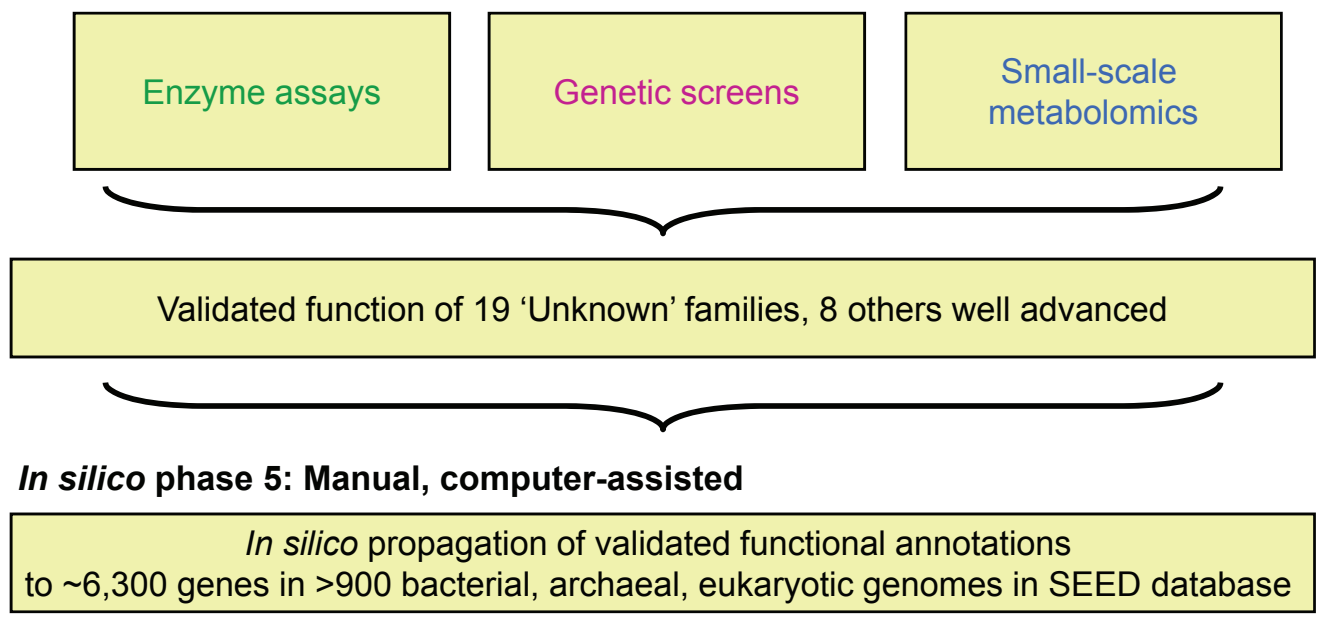

Figure 1 Project workflow. The overall strategy that combined in silico and experimental validation is presented showing the number of genes that were analyzed at each stage.

associated with SEED subsystems that are classified as non-hypothetical; i.e. encoding established metabolic pathways, physiological processes, or structural complexes (as opposed to experimental or hypothetical subsystems that group uncharacterized genes based on various criteria, including co-localization, co-regulation, common phenotype, etc.)

The list of Arabidopsis PUFs [22] served as a secondary resource. Three distinct PUF identification methods, complementary to our approach, have been used to 
Table 1 Selection of candidate hypothetical genes families conserved in Arabidopsis (AT) and prokaryotes for in silico functional predictions and potential experimental verification - an overview

\begin{tabular}{|c|c|c|c|c|c|c|c|c|}
\hline \multirow[t]{2}{*}{$\begin{array}{l}\text { AT gene } \\
\text { families in } \\
\text { this study }\end{array}$} & \multirow[t]{2}{*}{$\begin{array}{c}\text { AT genes } \\
\text { (and families) } \\
\text { screened }\end{array}$} & \multirow[t]{2}{*}{$\begin{array}{l}\text { AT genes with } \\
\text { prokaryote } \\
\text { homolog(s) }\end{array}$} & \multirow[t]{2}{*}{$\begin{array}{c}\text { AT genes } \\
\text { selected for in } \\
\text { silico analysis }\end{array}$} & \multirow[t]{2}{*}{$\begin{array}{l}\text { Gene families } \\
\text { connected to } \\
\text { metabolic areas }\end{array}$} & \multirow[t]{2}{*}{$\begin{array}{l}\text { Families with } \\
\text { specific } \\
\text { hypotheses } \\
\text { formulated }\end{array}$} & \multirow[t]{2}{*}{$\begin{array}{l}\text { Families } \\
\text { experimentally } \\
\text { tested in this } \\
\text { study }\end{array}$} & \multicolumn{2}{|c|}{$\begin{array}{l}\text { Families with } \\
\text { validated } \\
\text { functions - }\end{array}$} \\
\hline & & & & & & & $\begin{array}{c}\text { in } \\
\text { this } \\
\text { study }\end{array}$ & $\begin{array}{l}\text { by } \\
\text { others }\end{array}$ \\
\hline Singletons & 3,625 & 666 (18.4\%) & 178 & 42 & 21 & 10 & 3 & 5 \\
\hline Duplets & $\begin{array}{c}3,204(1,602 \\
\times 2)\end{array}$ & 909 (28.4\%) & 190 & 21 & 13 & 7 & 3 & 2 \\
\hline Triplets $^{a}$ & $2,421(807 \times 3)$ & 849 (35.0\%) & 262 & 14 & $\begin{array}{c}6 \\
(+1)^{\mathrm{b}}\end{array}$ & $\begin{array}{c}3 \\
(+1)^{\mathrm{b}}\end{array}$ & $\begin{array}{c}2 \\
(+1)^{\mathrm{b}}\end{array}$ & 3 \\
\hline Total & $9,250(6,034)$ & $2,325(25.1 \%)$ & 630 & 78 & 41 & $21^{c}$ & 9 & 10 \\
\hline
\end{tabular}

${ }^{a}$ Includes several Arabidopsis gene families with 4 or more paralogs

${ }^{b}$ One candidate was not in the Arabidopsis set (number 4 in Table 2).

c Includes 9 families with functions experimentally validated, 4 invalidated, and 8 for which experimental validation is currently in progress (see Table 2 and Table 3 for details)

compile this list: (i) BLASTP searches against proteins of known function in Swiss-Prot; (ii) Hidden Markov Model-derived searches against the Pfam domain database; and (iii) retrieval of the 'unknown' annotations from the Gene Ontology system [22]. Finally, to keep abreast of discoveries of functions for Arabidopsis genes, publications associated with selected Arabidopsis genes were extracted from the TAIR database and PubMed repeatedly during the course of this project.

This analysis yielded a set of 630 hypothetical Arabidopsis genes, corresponding to about 360 gene families common to Arabidopsis and prokaryotes that were highly enriched in those specifying proteins of unknown function. This gene set was then prioritized for in-depth in silico analysis as described below.

\section{Prioritizing Arabidopsis/prokaryotic gene families for detailed in silico analysis \\ General strategy}

As the pool of 360 gene families was still too large for the labor-intensive process of in-depth comparative genomic analysis, we prioritized the candidates for further analysis based on several characteristics associated with each protein-encoding gene in the SEED database. The main such characteristic was the presence of 'functional coupling' or 'conserved gene clustering' [24-27] for a prokaryotic member of the family, but other criteria were also computed when available as detailed below.

\section{Detecting and analyzing gene clustering}

Physical gene clustering is the tendency of functionally associated genes to be located near each other on the chromosome. Although not entirely absent in eukaryotes [28], such clustering is far more marked in prokaryotes, in which functionally related genes are often arranged in operons [29] or divergently transcribed from the same promoter region [24], or are simply neighbours or nearneighbours $[24,30]$. On average, $\sim 35 \%$ of bacterial metabolic genes are in clusters [24]. A key point is that the more taxonomically diverse the genomes in which a cluster occurs, the more informative the cluster becomes [30]. A single gene family can be involved in different clusters in different taxa (all potentially diagnostic of its function), even if it is not clustered with informative genes in all taxa.

Several software tools in SEED that take advantage of gene clustering were used to select promising candidates, as well as to link unknown gene families to general metabolic pathways and to generate specific functional predictions during the next phase of the project:

(i) Strength of 'functional coupling' (FC) - measures the number of distantly related organisms (with $95 \%$ overall DNA sequence identity or less) in which two genes are located in each other's vicinity. Close strains are not taken into account in this parameter, for example: all sequenced Escherichia coli genomes in SEED in which two particular genes are co-localized on the chromosome are counted as one when computing FC (see ref. [24] for a more formal treatment of this topic).

(ii) Length of cluster - reflects the number of genes involved in a specific cluster.

(iii) Evidence code 'in cluster with non-hypothetical' (cwn) - indicates that a gene family is functionally coupled to (tends to co-localize with) at least one other gene family that has been assigned a function that is considered 'non-hypothetical'. The functional coupling score must be five or more for this code to apply.

(iv) Evidence code 'in cluster with hypothetical' (cwh) - as above, except it labels gene families that tend to 
co-localize with at least one other hypothetical gene family;

(v) Association of a gene family with a 'clustering based' subsystem in SEED (CBSS). These subsystems group hypothetical protein families solely on the grounds of co-localization patterns conserved across multiple genomes; however, manual subsystem encoding takes automatically pre-computed leads (such as evidence codes) to the next level. For example, comprehensive phyletic spread is determined for protein families that might have been labeled as 'in cluster with hypothetical' in merely a fraction of genomes. CBSS subsystems provided a useful starting point for the next phase of in silico analysis.

\section{Other filtering factors}

Other factors that were considered included:

(i) Phyletic spread - the number of distinct microbial species that harbored members of each hypothetical family under consideration, whether or not they were functionally coupled (see above). Widely distributed families were preferred over narrowly distributed ones.

(ii) Whether or not well studied model organisms such as E. coli, Bacillus subtilis, Pseudomonas aeruginosa, cyanobacteria, or yeast contained a member of the gene family in question, indicating likely availability of functional genomics data (e.g. expression arrays, gene essentiality data, protein interaction datasets) that could provide clues linking candidate families to general metabolic areas and aid specific functional predictions.

Comprehensive tables summarizing all types of association evidence (available as Additional Files 1 and 2) were used for manual sorting and evaluation to prioritize hypothetical plant/prokaryote gene families and to select candidates for further detailed in silico analysis.

\section{Linking unknown gene families to general metabolic areas}

Our first goal was to link the prioritized gene families to a particular metabolic or functional area. For this, we built on the gene clustering associations captured as described above, using these to construct a corresponding experimental subsystem in the SEED database for each family (see Methods). Each such subsystem included all members of the focus gene family across all genomes available in the database, as well as gene families potentially associated with it (as implicated by gene clustering in at least a fraction of prokaryote genomes). Such integration of biological functions with genome sequences provided by subsystems allowed us to discard or strengthen the clustering associations and to evaluate the phylogenetic co-distribution between the gene family of interest and the associated families. We then further explored the associations by extending the analysis to Arabidopsis. Indeed, organization of genomic data in subsystems allows accurate extrapolation of functional associations between genes detected in microbial genomes onto other prokaryotes and even eukaryotes (e.g. Arabidopsis), albeit with caution. For example, in our study the degree of similarity between an Arabidopsis gene and its nearest prokaryotic homolog involved in gene clustering played an important role in evaluating the validity of such cross-kingdom projections. Additional 'checks and balances' were used in projecting functional leads and hypotheses developed via comparative analysis of prokaryotic genomes back to plant genes, which might not have preserved the function of their prokaryotic counterparts. For example, when linking unknown gene families to general metabolic areas, or to individual protein families via gene clustering, the validity of such associations in the context of plant physiology and biochemistry was considered, as well as its correspondence to Arabidopsis expression array data [31-33], protein localization [34,35], mutant phenotypes, and other functional genomics data (as illustrated in the case studies below). This first analysis yielded a list of 78 gene families linked to diverse metabolic areas (Additional file 2), including fatty acids, terpenes, vitamins, aromatic compounds, and sulfur, as well as iron-sulfur cluster assembly, oxidative damage protection, glutathione S-transferase-dependent detoxification, DNA repair, plastid/cell division, signalling systems, and metal homoeostasis. However, a clear bias reflecting the investigators' areas of expertise was observed, with some ten in vitamin/cofactor metabolism and another fourteen in tRNA/RNA modifications. This emphasizes the value of combining multiple types of expertise to accurately predict and validate gene function.

\section{Predicting and testing precise molecular and biological functions \\ General strategy}

The next step in the pipeline was creating a functional hypothesis that could be tested by genetic and/or biochemical experiments. This is by far the most labor intensive and intellectually challenging step in the pipeline. Multiple types of data need to be queried and integrated with biochemical insights in order to make reasonable and testable predictions. Clues can come from high-throughput data (protein complexes, phenotypes, microarrays) from any organism, from the literature (where data may be buried in supplemental tables and contain no reference to the gene family), or from analysis of the structure of a member of the family (e.g. from a structural genomics effort). Biochemical insight can come from cataloguing globally or locally missing genes, i.e. those that encode enzymes for which a gene has never been identified in any species or is absent in certain species [36-38]. 
An example of globally missing gene identified in this work is the Sua5/YrdC family involved in the universal carbamoylthreonyladenosine $\left(t^{6} \mathrm{~A}\right)$ modification in tRNA (case number 5 in Table 2 and summarized below). An example of a locally missing gene is the PTPS-III family (case number 4 in Table 2) that replaces the folate biosynthesis enzyme FolB in many bacteria and certain eukaryotes $[39,40]$. Biochemical insights can also come from noting the presence of two gene families annotated as fulfilling the same role, suggesting a possible duplication followed by functional divergence [41]. One such example is the COG0354 family, previously annotated in many genomes as the folate-dependent glycine cleavage system $\mathrm{T}$ protein $(\mathrm{GcvT})$, but in reality a protein involved in the repair of iron-sulfur clusters (case number 1 in Table 2 and summarized below). For some families very precise functions could be predicted, e.g. methylation of a specific position in ribosomal RNA (At4g28830, case number 31 in Table 3) whereas for others the prediction remained more general but testable nonetheless. For instance, we were able to link certain members of the COG0523 family (case number 7 in table 2) to zinc homeostasis [42] and this general prediction was borne out by demonstrating that some members of the family have a role in survival in low zinc conditions ([43] and C. Blaby-Haas and V. de Crécy-Lagard, unpublished results). We were able to make testable functional predictions for 41 families (Additional file 2); the rationales for these predictions are summarized in the subsystem notes for each family in the SEED database. Table 2 lists the 19 families for which the prediction has been experimentally confirmed by us or others. Table 3 lists four families that were experimentally invalidated and another eight for which experiments are well advanced, for a total of 31 families. Three illustrative examples of validated predictions are described briefly below. The first and second of these are fully described elsewhere [44,45].

\section{COG0354 (At4g12130, At1g60990)}

Bacterial genes encoding COG0354 (case number 1 in Table 2), the GcvT paralog noted above, often cluster with diverse iron/sulfur $(\mathrm{Fe} / \mathrm{S}$ ) proteins (shown in red in Fig. 2A), and proteomic data $[46,47]$ show induction by oxidative stress and confirm an $\mathrm{Fe} / \mathrm{S}$ association. Moreover, the COG0354 protein is required for full activity of certain $\mathrm{Fe} / \mathrm{S}$ enzymes in E. coli[48] and yeast [49]. We therefore predicted that COG0354 is a folate-dependent enzyme (based on its homology to the folatedependent protein GcvT) involved in assembly or repair of $\mathrm{Fe} / \mathrm{S}$ proteins, particularly under oxidative stress. Consistent with this prediction, deleting the gene encoding COG0354 in E. coli ( $y g f Z)$ increased oxidative stress sensitivity, and the stress-sensitive phenotype was complemented by expressing a plant COG0354 protein (Fig.
2B). Folate-dependence was established by using NMR to demonstrate stereoselective folate binding by recombinant E. coli COG0354, and by showing that in vivo activity of the E. coli $\mathrm{Fe} / \mathrm{S}$ protein $\mathrm{MiaB}$ is as seriously impaired by deleting the folate synthesis gene folE (which eliminates folates) as by deleting $y g f Z$, i.e. removing folates had the same impact as removing COG0354 [44].

\section{COG3643 (At2g20830)}

The histidine utilization (Hut) pathway occurs in certain bacteria and animals, but not plants. The Hut pathway up to the intermediate $\mathrm{N}$-formiminoglutamate is invariant, but thereafter there are three routes to the endproduct glutamate, one of which involves a formiminotransferase, COG3643 (Fig. 3A). Comparative genomics analysis showed that bacteria that have a formiminotransferase-type Hut pathway generally lack the $y g f A$ gene encoding 5-formyltetrahydrofolate cycloligase, the key enzyme required to recycle 5-formyltetrahydrofolate, which inhibits various folate-dependent enzymes and is formed by a side reaction of serine hydroxymethyltransferase in the presence of glycine (Fig. 3B). This striking observation led us to predict that formiminotransferase or formiminotransferase paralogs can replace YgfA. This prediction fits with classical biochemical data showing that mammalian formiminotransferase can mediate formyl transfer from 5-formyltetrahydrofolate to glutamate, albeit at a low rate $[50,51]$. The prediction was supported by showing that various prokaryotic COG3643 genes (highlighted in Fig. 3B) complement the growth phenotype of an E. coli $y g f A$ deletion mutant (which cannot use glycine as sole nitrogen source, presumably because 5 -formyltetrahydrofolate accumulation inhibits the folate-dependent glycine cleavage reaction). Representative data for the Acidobacterium COG3643 gene are shown in Fig. 3C. Folate analysis of the $y g f A$ deletant with and without complementing COG3643 genes confirmed that the deletant accumulated 5-formyltetrahydrofolate and that COG3643 genes reversed this accumulation [45]. Furthermore, characterization of recombinant COG3643 proteins showed their kinetic characteristics to be consistent with an in vivo role in 5formyltetrahydrofolate recycling [45]; this biochemical corroboration is important since functions carried out by ectopically overexpressed genes do not necessarily reflect their native function. Taken together, this evidence suggests that COG3643 paralogs in plants may likewise replace YgfA. Consistent with this possibility, the $y g f A$ knockout in Arabidopsis has a mild phenotype, pointing to the existence of an alternative route for disposal of 5-formyltetrahydrofolate [52].

YrdC/Sua5 (At5g60590)

The universal base modification $t^{6} \mathrm{~A}$ occurs at position 37 in a subset of tRNAs decoding ANN codons. The 
Table 2 Status of the experimentally validated families: cases 1-9 verified by us; cases 10-19 verified by others

\begin{tabular}{|c|c|c|c|c|c|c|c|}
\hline $\begin{array}{l}\text { Case } \\
\text { no. }\end{array}$ & TAIR ID & $\begin{array}{c}\text { COG } \\
\text { number/ } \\
\text { gene name }\end{array}$ & $\begin{array}{l}\text { Subsystem in } \\
\text { SEED }\end{array}$ & Working functional prediction & Experimental verification status & $\begin{array}{l}\text { Homologs } \\
\text { annotated }\end{array}$ & Reference \\
\hline 1 & $\begin{array}{l}\text { At } 4 g 12130 \\
\text { At1g60990 }\end{array}$ & 0354 ygfz & YgfZ & $\begin{array}{c}\text { Folate-dependent protein for Fe/S } \\
\text { cluster synthesis/repair in } \\
\text { oxidative stress }\end{array}$ & $\begin{array}{c}\text { Validated in E. coli, Bartonella } \\
\text { henselae, Haloferax volcanii, } \\
\text { Arabidopsis, Leishmania, yeast, } \\
\text { mouse }\end{array}$ & 327 & [44] (2010) \\
\hline 2 & At2g20830 & 3643 & $\begin{array}{l}\text { Experimental- } \\
\text { histidine } \\
\text { degradation }\end{array}$ & $\begin{array}{c}\text { Alternative to 5-FCL (EC 6.3.3.2) as } \\
\text { a way to metabolize 5- } \\
\text { formyltetrahydrofolate }\end{array}$ & Verified in 5 prokaryotes & 65 & [45] (2010) \\
\hline 3 & $\begin{array}{l}\text { At1g29810 } \\
\text { At5g51110 }\end{array}$ & 2154 phhB & $\begin{array}{l}\text { Pterin } \\
\text { carbinolamine } \\
\text { dehydratase }\end{array}$ & $\begin{array}{l}\text { Pterin-4-alpha-carbinolamine } \\
\text { dehydratase (EC 4.2.1.96) with a } \\
\text { role in Moco metabolism }\end{array}$ & $\begin{array}{c}\text { Validated in } 7 \text { eukaryotes and } 8 \\
\text { prokaryotes }\end{array}$ & 217 & [81] (2008) \\
\hline 4 & none & 0720 & $\begin{array}{l}\text { Experimental- } \\
\text { PTPS }\end{array}$ & Replacement for FolB (EC 4.1.2.25) & $\begin{array}{l}\text { Validated in } 1 \text { eukaryote and } 8 \\
\text { prokaryotes }\end{array}$ & 65 & $\begin{array}{l}\text { [40] (2009); } \\
\text { [39] (2008) }\end{array}$ \\
\hline 5 & At5g60590 & $0009 \mathrm{yrdC}$ & $\begin{array}{l}\text { YrdC-YciO- } \\
\text { Sua5 protein } \\
\text { family }\end{array}$ & $\begin{array}{c}\text { Required for threonylcarbamoyl- } \\
\text { adenosine }(\mathrm{t}(6) \mathrm{A}) \text { formation in } \\
\text { tRNA }\end{array}$ & $\begin{array}{c}\text { Validated in yeast, archaea and } 2 \\
\text { bacteria. } \\
\text { Arabidopsis in progress. }\end{array}$ & 745 & [60] (2009) \\
\hline 6 & $\begin{array}{l}\text { At2g45270 } \\
\text { At4g22720 }\end{array}$ & 0533 ygjD & $\begin{array}{l}\text { YrdC-YciO- } \\
\text { Sua5 protein } \\
\text { family }\end{array}$ & $\begin{array}{c}\text { Required for threonylcarbamoyl- } \\
\text { adenosine }(\mathrm{t}(6) \mathrm{A}) \text { formation in } \\
\text { tRNA }\end{array}$ & Validated in yeast & 691 & [82] (2011) \\
\hline 7 & $\begin{array}{l}\text { At1g15730 } \\
\text { At1g26520 } \\
\text { At1g80480 }\end{array}$ & 0523 & COG0523 & Diverse metal chaperones & Validated in several bacteria & 718 & [42] (2009) \\
\hline 8 & At3g13050 & $\begin{array}{l}\text { MFS } \\
\text { superfamily } \\
\text { NiaP } \\
\text { homolog }\end{array}$ & $\begin{array}{l}\text { Niacin-choline } \\
\text { transport and } \\
\text { metabolism }\end{array}$ & Niacin and/or choline transporter & $\begin{array}{c}\text { Niacin but not choline transport } \\
\text { shown for } 3 \text { bacterial proteins and } \\
\text { the mouse protein } \\
\text { Arabidopsis protein in progress. }\end{array}$ & 133 & $\begin{array}{l}\text { Manuscript } \\
\text { in prep }\end{array}$ \\
\hline 9 & At1g76730 & 0212 & $\begin{array}{l}\text { 5-FCL-like } \\
\text { protein }\end{array}$ & $\begin{array}{c}\text { Not a 5-FCL enzyme; involved in } \\
\text { thiamine salvage }\end{array}$ & $\begin{array}{l}\text { Cannot replace } 5-\mathrm{FCL} \text { and lacks } \\
\text { detectable 5-FCL activity }\end{array}$ & 41 & $\begin{array}{l}\text { Manuscript } \\
\text { submitted }\end{array}$ \\
\hline 10 & At4g36400 & $\begin{array}{c}0277 \\
\text { bll2569 }\end{array}$ & COG0277 & $\begin{array}{l}\text { D-2-hydroxyglutarate } \\
\text { dehydrogenase }\end{array}$ & $\begin{array}{l}\text { D-2-hydroxyglutarate } \\
\text { dehydrogenase }\end{array}$ & 158 & [83] (2009) \\
\hline 11 & At5g10910 & 0275 mraW & $\begin{array}{l}\text { 16S rRNA } \\
\text { modification } \\
\text { within P site } \\
\text { of ribosome }\end{array}$ & $\begin{array}{l}\text { SAM-dependent } \\
\text { methyltransferase involved in a } \\
\text { process common to eubacteria } \\
\text { and chloroplasts }\end{array}$ & $\begin{array}{l}16 \mathrm{~S} \text { rRNA m(4) C1402 } \\
\text { methyltransferase (modification } \\
\text { within P site of ribosome) }\end{array}$ & 877 & [84] (2010) \\
\hline 12 & At1g45110 & 0313 & $\begin{array}{l}16 \mathrm{~S} \text { rRNA } \\
\text { modification } \\
\text { within P site } \\
\text { of ribosome }\end{array}$ & $\begin{array}{c}\text { Tetrapyrrole family } \\
\text { methyltransferase involved in a } \\
\text { process common to eubacteria, } \\
\text { chloroplasts, and possibly } \\
\text { mitochondria }\end{array}$ & $\begin{array}{l}165 \text { rRNA 2'-O-ribose C1402 } \\
\text { methyltransferase (modification } \\
\text { within P site of ribosome) }\end{array}$ & 836 & [84] (2010) \\
\hline 13 & $\begin{array}{l}\text { At5g18570 } \\
\text { At1g07620 }\end{array}$ & 0536 & lojap & $\begin{array}{l}\text { At5g18570 predicted to be } \\
\text { plastidial, At1g07615 } \\
\text { mitochondrial. Association } \\
\text { evidence connects At5g18570 } \\
\text { with plastidial iojap (At3g12930) }\end{array}$ & $\begin{array}{l}\text { Essential for embryo development } \\
\text { but specific function unclear }\end{array}$ & 721 & [85] (2009) \\
\hline 14 & At1g49350 & 2313 yeiN & $\begin{array}{l}\text { Pseudouridine } \\
\text { catabolism }\end{array}$ & Sugar catabolism & $\begin{array}{c}\text { Involved in pseudouridine } \\
\text { metabolism in uropathogenic } E \text {. } \\
\text { coli }\end{array}$ & 108 & $\begin{array}{l}\text { In EC: [86] } \\
\quad(2008)\end{array}$ \\
\hline 15 & At1g50510 & 0524 yeic & $\begin{array}{l}\text { Pseudouridine } \\
\text { catabolism }\end{array}$ & Sugar catabolism & $\begin{array}{c}\text { Involved in pseudouridine } \\
\text { metabolism in uropathogenic } E \text {. } \\
\text { coli }\end{array}$ & 108 & $\begin{array}{l}\text { In EC: [86] } \\
\quad(2008)\end{array}$ \\
\hline 16 & $\begin{array}{l}\text { At } 4 g 10620 \\
\text { At3g57180 } \\
\text { At3g47450 }\end{array}$ & 1161 yqeH & $\begin{array}{l}\text { At4g10620 } \\
\text { At3g57180 } \\
\text { At3g47450 }\end{array}$ & $\begin{array}{l}\text { GTP-binding protein YqeH, } \\
\text { involved in replication initiation }\end{array}$ & $\begin{array}{l}\text { At3g57180 (BPG2) functions in } \\
\text { brassinosteroid-mediated post- } \\
\text { transcriptional accumulation of } \\
\text { chloroplast rRNA. At3g47450 } \\
\text { (AtNOA1) is a GTPase that } \\
\text { regulates nucleic acid recognition }\end{array}$ & 180 & $\begin{array}{l}{[87](2010)} \\
{[88](2008)}\end{array}$ \\
\hline 17 & $\begin{array}{l}\text { At3g24430 } \\
\text { At4g19540 } \\
\text { At5g50960 }\end{array}$ & $2151 \mathrm{apbC}$ & $\begin{array}{l}\text { Scaffold } \\
\text { proteins for } \\
\text { [4Fe-4S] } \\
\text { cluster } \\
\text { assembly (MRP } \\
\text { family) }\end{array}$ & $\begin{array}{l}\text { Fe-S cluster assembly proteins. } \\
\text { The DUF59 (PaaD-like) domain of } \\
\text { At3g24430 and its prokaryotic } \\
\text { counterparts are also predicted to } \\
\text { function in Fe-S cluster assembly. }\end{array}$ & $\begin{array}{l}\text { At5g50960 (Nbp35) functions in } \\
\text { Fe-S cluster assembly as a } \\
\text { bifunctional molecular scaffold } \\
\text { At3g24430 acts as a scaffold } \\
\text { protein for [4Fe-4S] cluster } \\
\text { assembly in chloroplasts }\end{array}$ & 276 & $\begin{array}{l}{[89](2009)} \\
{[90](2005)}\end{array}$ \\
\hline
\end{tabular}


Table 2 Status of the experimentally validated families: cases 1-9 verified by us; cases 10-19 verified by others (Continued)

\begin{tabular}{|c|c|c|c|c|c|c|c|}
\hline 18 & At3g57000 & 1756 & $\begin{array}{c}\text { rRNA } \\
\text { modification } \\
\text { Archaea; rRNA } \\
\text { methylation in } \\
\text { clusters }\end{array}$ & rRNA modification enzyme & $\begin{array}{l}\text { The Methanocaldococcus } \\
\text { jannaschii ortholog is a } \\
\text { pseudouridine-N1-specific } \\
\text { methyltransferase. }\end{array}$ & 31 & [91] (2010) \\
\hline 19 & At5g12040 & 0388 & $\begin{array}{l}\text { Omega- } \\
\text { amidase }\end{array}$ & $\begin{array}{l}\text { Omega amidase in methionine } \\
\text { salvage pathway }\end{array}$ & $\begin{array}{l}\text { Biochemical characterization of } \\
\text { the rat and mouse orthologs }\end{array}$ & 113 & $\begin{array}{l}\text { [92] (2009) } \\
\text { [93] (2009) }\end{array}$ \\
\hline
\end{tabular}

biogenesis of this complex modification is yet to be elucidated but is known to require threonine, ATP, and bicarbonate [53-55]. COG0009 was predicted as a possible candidate for a missing $\mathrm{t}^{6} \mathrm{~A}$ biosynthesis family because it occurs in all genomes sequenced to date, is known to bind double-stranded RNA [56], and has been linked to defects in translation in both prokaryotes and eukaryotes $[57,58]$. This conjecture was supported by sequence homology with the [Ni-Fe] hydrogenase maturation protein $\mathrm{HypF}$, which catalyzes a reaction

Table 3 Status of the families invalidated by us (cases 20-23) or in progress (cases 24-31)

\begin{tabular}{|c|c|c|c|c|c|c|}
\hline $\begin{array}{l}\text { Case } \\
\text { no. }\end{array}$ & TAIR ID & $\begin{array}{l}\text { COG } \\
\text { number/ } \\
\text { gene } \\
\text { name }\end{array}$ & $\begin{array}{l}\text { Subsystem } \\
\text { in SEED }\end{array}$ & Working functional prediction & Experimental verification status & $\begin{array}{l}\text { Homologs } \\
\text { annotated }\end{array}$ \\
\hline 20 & At5g43600 & 0624 & $\begin{array}{l}\text { Experimental } \\
\text { - Histidine } \\
\text { Degradation }\end{array}$ & $\begin{array}{c}\text { Alternative form of } \mathrm{N} \text {-formylglutamate } \\
\text { deformylase (EC 3.5.1.68) }\end{array}$ & $\begin{array}{l}\text { No deformylase actiivity detected in } \\
\text { Streptomyces avermitilis protein }\end{array}$ & $24^{\mathrm{a}}$ \\
\hline 21 & At2g23390 & 3146 & COG3146 & Pterin-dependent enzyme & $\begin{array}{c}\text { Xanthomonas campestris protein lacks } \\
\text { benzoate hydroxylase activity in } \\
\text { complementation assay }\end{array}$ & 236 \\
\hline 22 & At2g04900 & $\begin{array}{l}2363 \\
y w d K\end{array}$ & COG2363 & Thiamine-related transporter & $\begin{array}{l}\text { E. coli protein does not mediate } \\
\text { uptake of thiazole or } \\
\text { hydroxymethylpyrminidine }\end{array}$ & 221 \\
\hline 23 & At1g09150 & 2016 & $\begin{array}{l}\text { rRNA } \\
\text { modification } \\
\text { Archaea; } \\
\text { DOE- } \\
\text { COG2016 }\end{array}$ & Ribosome assembly/translation termination & $\begin{array}{c}\text { In progress in yeast and } \mathrm{H} \text {. volcanii. } \\
\text { Hypothesis that it is involved in } \\
\text { acp3psi synthesis invalidated by } \\
\text { Fournier lab } \mathbf{b}^{\mathbf{b}}\end{array}$ & 30 \\
\hline 24 & $\begin{array}{l}\text { At4g26860 } \\
\text { At1g11930 }\end{array}$ & $\begin{array}{l}0325 \\
\text { yggS }\end{array}$ & PROSC & $\begin{array}{l}\text { Pyridoxal phosphate enzyme related to } \\
\text { glutamate metabolism }\end{array}$ & In progress in E. coli & 589 \\
\hline 25 & $\begin{array}{l}\text { At1g78620 } \\
\text { At5g19930 }\end{array}$ & $\begin{array}{l}1836 \\
\text { alr1612 }\end{array}$ & COG1836 & Phytol-phosphate metabolism & $\begin{array}{c}\text { Shown to be an essential gene in } \\
\text { Synechocystis } 6803 \text {. Further work in } \\
\text { progress in Arabidopsis }\end{array}$ & 77 \\
\hline 26 & $\begin{array}{l}\text { At5g12950 } \\
\text { At5g12960 }\end{array}$ & $\begin{array}{c}3533 \\
\text { SAV1144 }\end{array}$ & $\begin{array}{c}\text { DOE } \\
\text { COG3533 }\end{array}$ & Hydroxyproline-galactosyl hydrolase & In progress in $X$. campestris & 82 \\
\hline 27 & At3g09250 & $\begin{array}{c}4319 \\
\text { gll0142 }\end{array}$ & COG4319 & $\begin{array}{c}\text { Folate or pterin metabolism enzyme, } \\
\text { possibly an alternative DHFR (EC 1.5.1.3), a } \\
\text { pterin reductase, or a dihydroneopterin } \\
\text { triphosphate hydrolase }\end{array}$ & $\begin{array}{c}\text { Streptomyces coelicolor, Arabidopsis } \\
\text { At3g09250, and Nostoc punctiforme } \\
\text { proteins failed to complement E. coli } \\
\text { folA (DHFR) strains }\end{array}$ & 59 \\
\hline 28 & $\begin{array}{l}\text { At3g12930 } \\
\text { At1g67620 }\end{array}$ & $\begin{array}{c}0799 \\
\text { alr4169 }\end{array}$ & lojap & $\begin{array}{l}\text { NAD-dependent ribosomal modification, } \\
\text { possibly involving phosphoester hydrolysis }\end{array}$ & $\begin{array}{l}\text { No pyrophosphatase or NAD cleavage } \\
\text { activity detected in E. coli YbeB or } \\
\text { NadD-YbeB fusion protein from } \\
\text { Wolinella succinogenes }\end{array}$ & 672 \\
\hline 29 & At3g01920 & 0009 yсiO & $\begin{array}{l}\text { YrdC-YciO- } \\
\text { Sua5 protein } \\
\text { family }\end{array}$ & RNA/protein modification & In progress in E. coli & 195 \\
\hline 30 & At1g03030 & $\begin{array}{l}1072 \\
\operatorname{yggC}\end{array}$ & $\begin{array}{l}\text { Experimental- } \\
\text { yggC }\end{array}$ & Sugar/polyol kinase & In progress in E. coli & 48 \\
\hline 31 & At4g28830 & 2263 & $\begin{array}{c}\text { rRNA } \\
\text { modification } \\
\text { Archaea }\end{array}$ & Predicted RNA methylase COG2263 & In progress in $\mathrm{H}$. volcanii & 49 \\
\hline
\end{tabular}

\footnotetext{
${ }^{a}$ Numbers in italics are for members of families for which the prediction has been invalidated or is in progress, they have not been included in the final count.

${ }^{\mathrm{b}}$ S. Fournier and W. Decatur, University of Massachusetts (unpublished).
} 


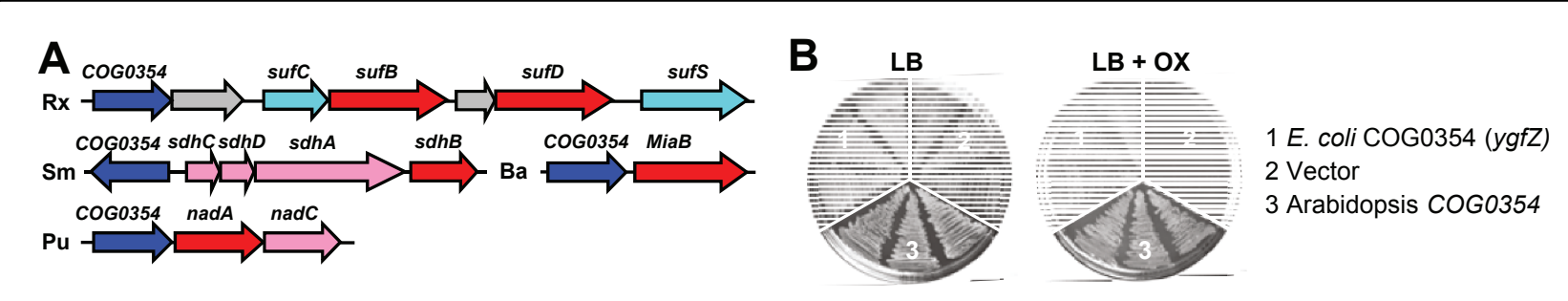

Figure 2 Clustering arrangements of genes encoding COG0354 and functional complementation of an E. coli COG0354 deletant by an Arabidopsis COG0354. (A) Clustering of COG0354 genes with Fe/S-related genes. Blue, COG0354; red, Fe/S proteins; rose, proteins in same complex or pathway as Fe/S proteins; turquoise, Fe/S cluster assembly proteins. Rx, Rubrobacter xylanophilus; Sm, Stenotrophomonas maltophilia; Pu, Pelagibacter ubique. (B) Growth of an E. coli COG0354 (ygfZ) deletant harboring plasmid-borne E. coli ygfZ, Arabidopsis mitochondrial COG0354, or vector alone on LB medium or LB plus the oxidative stress agent plumbagin $(\mathrm{OX})(30 \mu \mathrm{M})$, arabinose $(0.02 \% \mathrm{~W} / \mathrm{V})$, and appropriate antibiotics.

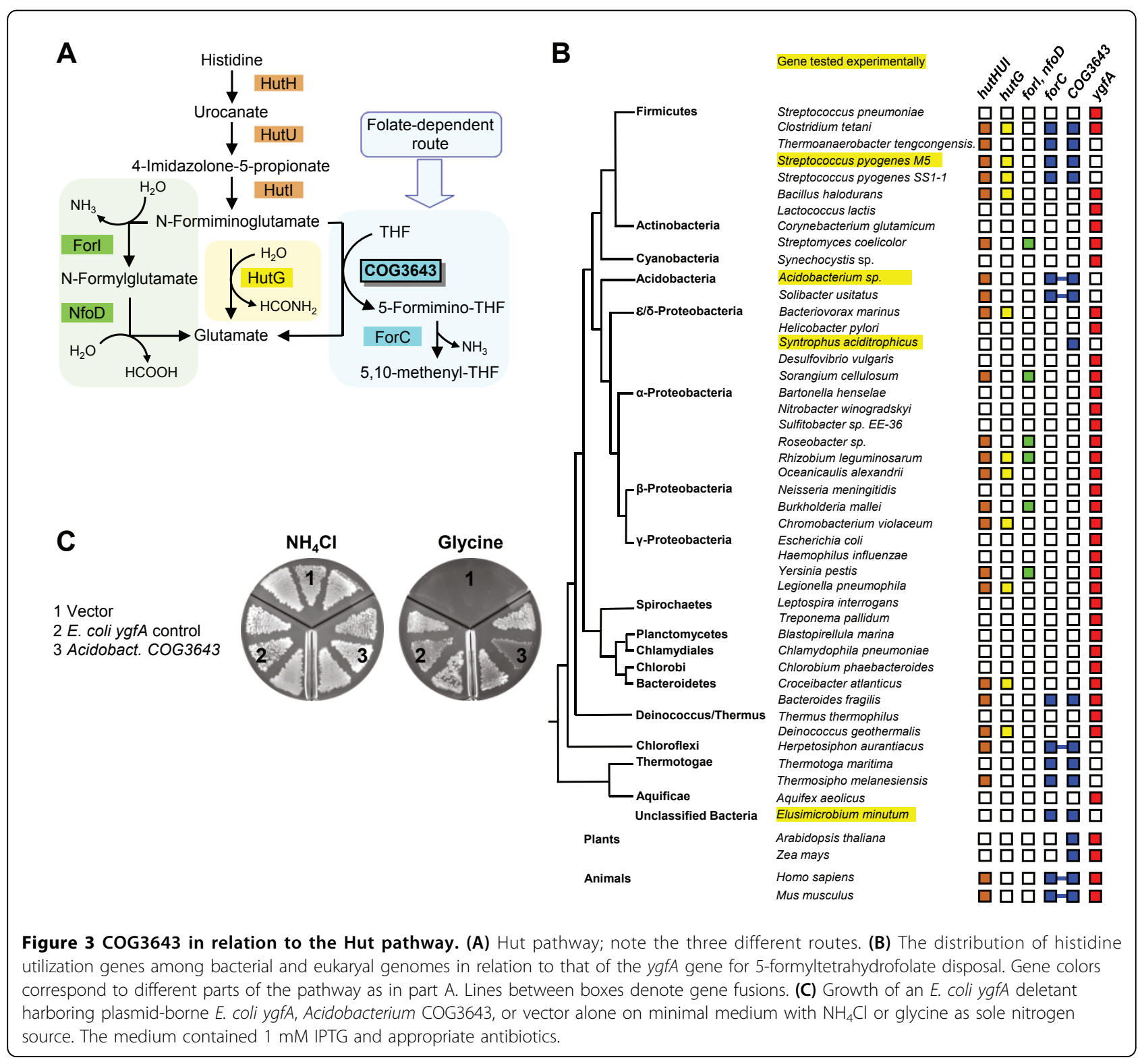


analogous to the one expected for a $t^{6} \mathrm{~A}$ enzyme [59]. The COG0009 family can be further split based on sequence comparison into three subfamilies: YrdC, Sua5 (YrdC with an extra domain termed Sua5), and YciO. One or two members of this family are present in each genome; for example, the Arabidopsis and E. coli genomes contain two, YrdC (At5g60590) and YciO (At3g01920), while the Saccharomyces cerevisiae genome contains only one, Sua5 [60]. We showed that (i) tRNAs from $S$. cerevisiae strains lacking sua5 do not contain $t^{6} \mathrm{~A}$ and that this phenotype is complemented by transforming with a plasmid encoding the wild type gene (Fig. 4A); (ii) the homologs from B. subtilis, M. maripaludis, E. coli yrdC, but not E. coli yciO also complement the phenotype; (iii) the $y \mathrm{rdC}$ homolog is essential in
E. coli, whereas $y c i O$ is not; (iv) S. cerevisiae, B. subtilis, $M$. maripaludis $y r d C$ genes but not $E$. coli $y c i O$ are able to complement the lethality phenotype of $y \mathrm{rdC}$ in E coli (Fig. 4B); and (v) E. coli $y r d C$ is able to bind $\mathrm{t}^{6} \mathrm{~A}$ apomodified tRNA ${ }^{\text {Thr }}$ but not unmodified transcript [60]. Therefore, members of the YrdC/Sua5 family are involved in $\mathrm{t}^{6} \mathrm{~A}$ biosynthesis. In Arabidopsis, At5g60590 and At3g01920 are annotated as related to the YrdC family. However, based on comparative sequence analysis combined with genetic orthologous complementation tests these can be distinguished. As depicted in Fig. 4C, the YrdC family is characterized by the KxR/G ...SxN signature sequence; At5g60590 is therefore most probably part of the YrdC family while At3g01920 is not.
A

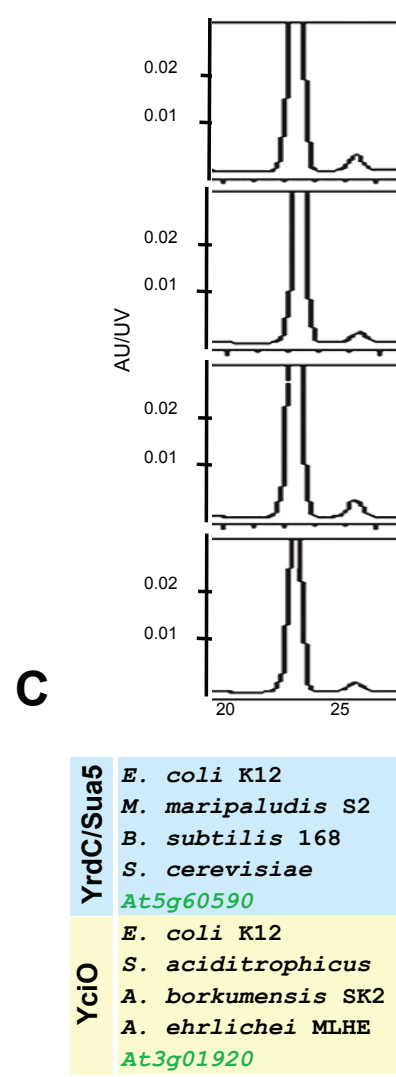

B

pBAD24

pBAD24EcyrdC

pBAD24Ecycio

Sc sua5<smiles>CCCC</smiles>

Ec yrdC

pBAD24BsywIC

pBAD24Scsua5

pBAD24Mmsua5

Ec yciO
MG1655 $\mathrm{P}_{\text {Tet: }}: y r d C$
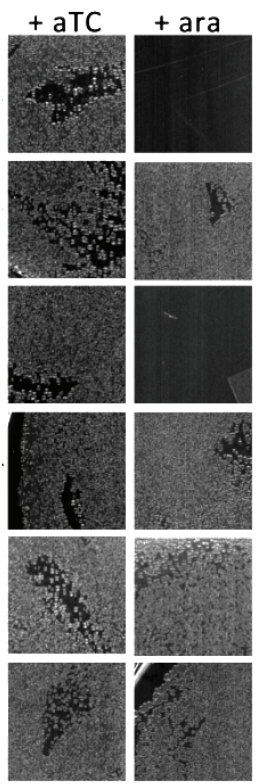
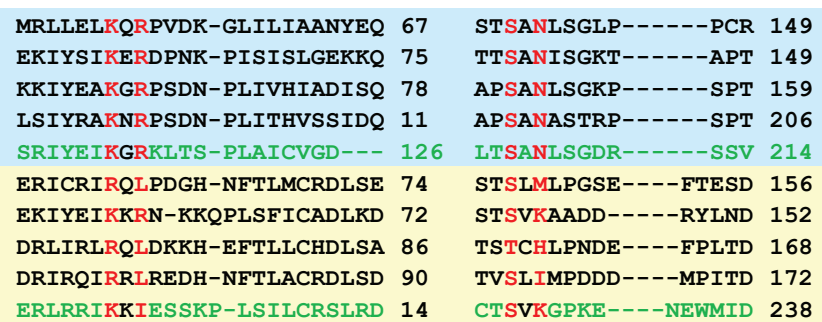

Figure 4 Separation of the COG009 family into two subgroups YrdC and YciO based on motifs and functional assays. (A) Complementation of the $t^{6} \mathrm{~A}^{-}$phenotype of the yeast $\triangle$ sua5 (YGN63) strain by the E. coli yrdC gene but not the E. coli yciO gene. (B) Complementation of the $y r d C$ essentiality phenotype in E. coli by yrdC subfamily members from E .coli (EcyrdC), Bacillus subtilis (BsywlC), Methanococcus maripaludis (MmyrdC) and yeast (Scsua5) but not by yciO from E. coli (EcyciO). All genes were cloned in pBAD24 [95] and were therefore expressed in the presence of arabinose (Ara, $0.2 \%$ ) and transformed in an E.coli strain carrying the chromosomal copy of yrdC under $\mathrm{P}_{\text {Tet }}$ control [96] that does not grow in the absence of anhydrotetracycline (ATc, $50 \mathrm{ng} / \mathrm{ml}$ ). (C) Signature motif of the functional homologs of $\mathrm{YrdC}(\mathrm{K} \times \mathrm{R} / \mathrm{S} \times \mathrm{N})$ that are not found in the YciO subfamily. In green are the two homologs from Arabidopsis and their distribution. 


\section{Propagating validated and predicted gene functions to other organisms}

Subsystem-based organization of genomic data in SEED implies delineation and maintenance of isofunctional gene groups [61]. This strategy greatly facilitates not only the development of functional predictions for uncharacterized genes, but also accurate projection of this knowledge, once verified, to other species. For example, annotations for the 19 families developed in the course of this study and experimentally confirmed by us or others have been propagated to a total of 6,297 genes in some 900 complete or nearly complete bacterial, archaeal, and eukaryotic genomes currently available in the SEED database (Table 2). Furthermore, we believe there is merit in accurate and exhaustive propagation of yet untested predictions to all orthologs in all available genomes, early in the process of in silico analysis. This allows complete and accurate cataloguing of functional homologs for each gene family under study, thus revealing its phyletic spread, co-occurrence with known gene families, potential associations with specific features of an environmental niche - all of which can serve as additional clues for developing specific functional hypotheses. For this reason we have built subsystems in the public SEED database for 78 families (Additional file 2) so that readers can produce and test their own predictions for gene families that fall in their area of expertise. The total number of annotated genes in these families exceeds 22,000.

\section{Comparing results to those from automated functional prediction platforms}

Several recently developed platforms seek to automatically integrate comparative genomics, high-throughput experimental data, and literature reports to make gene function predictions $[46,62]$. For ten gene families that were predicted and validated, we analyzed the accuracy of the corresponding predictions from the two most relevant predictions platforms, eNet (E. coli) [46] and AraNet (Arabidopsis) [62] (Table 4). The predictions from these automated platforms were mostly wrong. At best, they produced a general annotation that was in the right functional area such as 'folate dependent regulatory protein' by eNet and 'iron-sulfur assembly protein' by AraNet for the COG0354 family. However, both of these came straight from the literature, not from associations, and can thus hardly be called predictions; furthermore, these two correct 'predictions' were buried in long lists of incorrect ones. Thus, whenever a prediction was possible, the automated platforms failed to make a correct and precise one.

\section{Conclusions}

The analysis presented here shows that combining comparative genomics with expert intellectual input enabled correct functional annotation of 19 gene families by only a few researchers, in a short time (three years), and at a moderate cost $(<\$ 1 \mathrm{M})$. This number of successful functional predictions is roughly comparable to the number made through the entire structural genomics effort [63], involving many more people, a much longer period, and far greater expense. The cost-effectiveness of our approach is thus perhaps its most striking feature.

Our analysis also underscores the imperative of combining molecular function and biological context to annotate function as shown in the COG3643 example. Homology and even in vitro assays would have labeled this family - correctly, but incompletely and misleadingly - as a formiminotransferase. Only by interpreting phylogenetic distribution data with biochemical insight and then applying complementation tests was this family correctly annotated as an alternative to 5-formyltetrahydrofolate cycloligase to metabolize 5-formyltetrahydrofolate. It is noteworthy that in this and most of our other successful predictions, there is a strong bias towards the authors' areas of expertise - from which the obvious inference is that other experts would, equally easily, have been able to predict additional sets of functions. For this reason we have built subsystems in the public SEED database for 78 families and made available the raw comparative genomic data for all gene families shared between Arabidopsis and prokaryotes (Additional file $1 \mathrm{~A}, 1 \mathrm{~B}$, and $1 \mathrm{C}$ ) so that other experts can bring their insight to our analysis in order to make and test their own predictions.

Finally, the only plant genomes available when this effort started were Arabidopsis, rice, and poplar, and rich post-genomic resources were available only for Arabidopsis. We accordingly focused our work on gene families common to Arabidopsis and prokaryotes. However, now that other plant genomes are pouring in (some 20 are available already and many more are in the pipeline) it is clear that almost all of the families we investigated have orthologs in other plants, making our work of immediate value in annotating other plant genomes. Furthermore, the rapid growth of microarray databases and other post-genomic resources for plants besides Arabidopsis (e.g. [64-66]) is providing many sources of association evidence to reinforce the approach that we have pioneered here.

\section{Methods}

\section{Bioinformatics}

The SEED genomic database and software suite [10], publicly available at http://theseed.uchicago.edu/ (see http://TheSEED.org for access to data relating to the SEED Project) was the main comparative genomics platform of this study. This database hosts all validated and 
Table 4 Comparison of functional predictions in eNet and AraNet for 10 of the protein families

\begin{tabular}{|c|c|c|c|}
\hline TAIR ID & $\begin{array}{c}\text { E.coli } \\
\text { ortholog }\end{array}$ & Working functional prediction & eNet predictions \\
\hline $\begin{array}{l}\text { At4g12130, } \\
\text { At1g60990 }\end{array}$ & YgfZ & $\begin{array}{c}\text { Folate-dependent protein for } \mathrm{Fe} / \mathrm{S} \\
\text { cluster synthesis/repair in oxidative } \\
\text { stress }\end{array}$ & $\begin{array}{c}\text { Annotation based on[ 94]: Predicted } \\
\text { folate-dependent regulatory protein. } \\
\text { Prediction: Energy production and } \\
\text { conversion, ion transport }\end{array}$ \\
\hline At2g20830 & none & $\begin{array}{c}\text { Alternative to 5-FCL (EC 6.3.3.2) as } \\
\text { a way to metabolize } 5- \\
\text { formyltetrahydrofolate }\end{array}$ & $\mathrm{n} / \mathrm{a}$ \\
\hline $\begin{array}{l}\text { At1g29810, } \\
\text { At5g51110 }\end{array}$ & none & $\begin{array}{l}\text { Pterin-4-alpha-carbinolamine } \\
\text { dehydratase (EC 4.2.1.96) with a } \\
\text { role in Moco metabolism }\end{array}$ & $\mathrm{n} / \mathrm{a}$ \\
\hline AT5g12040 & YafV & $\begin{array}{l}\text { Omega amidase in methionine } \\
\text { salvage pathway }\end{array}$ & $\begin{array}{l}\text { Predicted C-N hydrolase family amidase, } \\
\text { NAD(P)-binding }\end{array}$ \\
\hline At5g60590 & YrdC & $\begin{array}{l}\text { Required for } \\
\text { threonylcarbamoyladenosine }(\mathrm{t}(6) \mathrm{A}) \\
\text { formation in tRNA }\end{array}$ & $\begin{array}{c}\text { Annotation based on [ 57]: Predicted } \\
\text { ribosome maturation factor. NO } \\
\text { prediction }\end{array}$ \\
\hline
\end{tabular}

At2g45270,

At4g22720

At1g15730

At1g26520,

At1g80480

$\begin{array}{cc}\text { At1g76730 none } & \begin{array}{c}\text { Not a 5-FCL enzyme; involved in } \\ \text { thiamine salvage }\end{array} \\ \text { At4g36400 none } & \begin{array}{c}\text { D-2-hydroxyglutarate } \\ \text { dehydrogenase }\end{array}\end{array}$

At1g45110 yraL Tetrapyrrole family methyltransferase involved in a process common to eubacteria chloroplasts, and possibly mitochondria
AraNet predictions ${ }^{\mathrm{a}}$

For At4g12130: NAD biosynthesis (2.96), electron transport, cellular respiration, Nterminal protein amino acid modification, miRNA-mediated gene silencing, production of miRNAs, methylglyoxal catabolic process to D-lactate, embryonic development, etc

Response to wounding (1.86), defense response, response to oxidative stress, phenylpropanoid biosynthesis, response to other organism, boron transport, glucosinolate biosynthesis (0.89)

For At1929810: electron transport (3.13); carotenoid biosynthesis (2.29);

brassinosteroid biosynthesis (2.16); fatty acid metabolic process (2.06);

photosynthesis, light reaction (1.99); sulfate assimilation (1.98); lignin biosynthesis

$$
\text { (1.87) }
$$

indoleacetic acid biosynthesis (4.27), cellular response to sulfate starvation, cyanide metabolic process, glucosinolate catabolic process, detoxification of nitrogen compound, methylglyoxal catabolic process to D-lactate (1.59)

rRNA processing (3.88), dATP biosynthesis from ADP, histidine biosynthesis, mitochondrial ATP synthesis coupled proton transport, cellular respiration, ATP synthesis coupled proton transport, regulation of transcription (2.07)

Prediction: Predicted peptidase (Amino acid transport and metabolism)

For At2g45270: transcription initiation (6.19), positive regulation of transcription, chlorophyll biosynthesis, porphyrin biosynthesis, phospholipid biosynthesis, electron transport, ATP-dependent proteolysis, $\mathrm{N}$-terminal protein amino acid modification (1.81)

For At1g15730: nitrogen compound metabolic process (4.04); positive

Prediction for b4352: Inorganic ion transport and metabolism, response to stress; Prediction for b2173: Lipid transport and metabolism, RNA related, Regulation of transcription DNA dependent $n / a$ $n / a$

Prediction: Replication, recombination and repair; RNA related, Translation regulation of metalloenzyme activity (4.04)

Tetrahydrofolate metabolic process (4.56), negative regulation of transcription, response to abscisic acid stimulus (0.89)

Cytoskeleton organization and biogenesis (2.39), actin cytoskeleton organization and biogenesis, ubiquitin-dependent protein catabolic process, response to light stimulus, response to wounding, seed germination (1.24)

Toxin catabolic process (5.49), response to oxidative stress, cellular response to water deprivation, response to jasmonic acid stimulus, response to ozone, isoprenoid biosynthesis, electron transport (1.45)

${ }^{a}$ Only a few top predictions (out of 30 routinely returned) for AraNet are shown. They are sorted by the AraNet score estimating the gene's association with each particular process (given in brackets for the first and last predictions shown here). 
proposed functional predictions developed in the course of this study for 78 genes families analysed in this study.

The SEED organizes genomic data in the form of subsystems (typically metabolic pathways or structural complexes) covering all organisms rather than on an organism-by-organism basis. Subsystems are developed and maintained by experts to capture the current status of knowledge of specific biological processes in model, well characterized organisms and to project this knowledge to other species via comparative genomics and metabolic reconstruction techniques [10]. Each subsystem includes a set of functionally related protein families (jointly encoding a specific pathway, process, or structural complex) across all available genomes (874 bacterial, 58 archaeal, and 29 eukaryotic complete and nearly complete genomic sequences as of July 2010). In SEED large homology-based protein families are broken into isofunctional subfamilies ('functional roles') based on genome context, functional context, phyletic profiling, shared regulatory sites, and other homology-independent clues. Association of each functional role with the corresponding subsystem(s) provides rich two-dimensional functional/phylogenetic context for each subfamily, leading to far more accurate annotations than the usual approach of annotating the genes within a single organism. Furthermore, the subsystem spreadsheet is used in SEED as a framework for integration of various types of functional data organized as gene attributes (e.g. gene clustering on a chromosome, expression array data, gene essentiality, etc.) and organism attributes (oxygen requirement, motility, pathogenicity, etc), which provide valuable non-homology based clues for functional predictions for uncharacterized genes.

All Subsystems created in this study, as well as over 1300 resident subsystems in SEED encoding all aspects of microbial physiology and metabolism are available on the public SEED server at http://theseed.uchicago.edu/ FIG/SubsysEditor.cgi. They are regularly updated to accommodate newly sequenced bacterial genomes as well as novel experimental data and other relevant data as they become available.

Phylogenetic occurrence profiles were analysed using the Signature Genes tool on the NMPDR server (http:// www.nmpdr.org/FIG/wiki/view.cgi/FIG/SigGenes). This tool identifies gene families that are common to a selected group of genomes, or those that differentiate one group of genomes from another. Annotations for paralog families were made using physical clustering when possible or by building phylogenetic trees using the ClustalW tool $[67,68]$ integrated in SEED or deriving specific motifs.

We also used the bioinformatic tools and resources at NCBI (http://www.ncbi.nlm.nih.gov) and KEGG (http:// www.genome.jp/kegg) [69], BRENDA (http://www. brenda-enzymes.info/) [70], PHYRE (Protein Homology/ analogY Recognition Engine http://www.sbg.bio.ic.ac.uk/ phyre/) [71], the Pfam database (http://pfam.sanger.ac. uk) [72], and specialized genomic resources and collections of functional genomic data for Arabidopsis, yeast, and various bacterial species, including: TAIR (The Arabidopsis Information Resource http://www.arabidopsis. $\operatorname{org} /$ ) [21]; SGD (Saccharomyces Genome Database http://www.yeastgenome.org) [22]; MicrobesOnline (http://www.microbesonline.org/) [73]; EcoGene (http:// ecogene.org/) [74]; EcoCyc (Encyclopedia of E. coli genes and metabolism (http://biocyc.org/ECOLI/) [75]; Cyanobase (http://genome.kazusa.or.jp/cyanobase) [76]; Pseudomonas genome database (http://www.pseudomonas.com/) [77]; and Rhodobase (http://rhodobase.org/ index.php). Collections of Arabidopsis global expression and proteomics data with on-line tools for visualization and analysis: ATTED (http://www.atted.bio.titech.ac.jp/) [78]; Golm Transcriptome database (http://csbdb. mpimp-golm.mpg.de/csbdb/dbxp/ath/ath_xpmgq.html, [31-33]); PED, Plant Gene Expression Database (http:// bioinfo.ucr.edu/projects/Unknowns/external/express. html); Genevestigator (https://www.genevestigator.com) [31-33]; PPDB, The Plant Proteome Data Base (http:// ppdb.tc.cornell.edu/) [79]; PDB, The Protein Data Base (http://www.rcsb.org/pdb/home/home.do) [80].

\section{Experimental validations}

Methods for the three experimental validation vignettes described above are already, or soon will be, described in the authors' publications.

\section{Additional material}

Additional file 1: Gene families shared between plants and prokaryotes: unique Arabidopsis genes (1A), paralogous Arabidopsis gene families with 2 members (1B), paralogous Arabidopsis gene families with 3 members (1C).

Additional file 2: Gene families shared between plants and Prokaryotes, that were linked to general areas of metabolism and physiology, or associated with more specific potential functions. All additional files table were also made available on: http://www. theseed.org/Papers/20101120/.

\section{Acknowledgements}

This work was supported by the U.S. Department of Energy (grant no. DEFG02-07ER64498) to $V$ de C-L and ADH and by an endowment from the C. V. Griffin, Sr. Foundation to $A D H . M B$ is a recipient of a postdoctoral fellowship from Human Frontier Scientific Program (HFSP). We thank Brian Haas for help and advice in identifying Arabidopsis gene families having three or fewer members, and Skip Fournier and Wayne Decatur for rRNA analysis in yeast.

This article has been published as part of BMC Genomics Volume 12 Supplement 1, 2011: Validation methods for functional genome annotation. The full contents of the supplement are available online at http://www. biomedcentral.com/1471-2164/12?issue=S1. 


\section{Author details}

${ }^{1}$ Fellowship for Interpretation of Genomes, Burr Ridge, IL, USA. ${ }^{2}$ Department of Microbiology and Cell Science, University of Florida, Gainesville, FL, USA. ${ }^{3}$ Department of Horticultural Sciences, University of Florida, Gainesville, $\mathrm{FL}$, USA. ${ }^{4}$ Computation Institute, University of Chicago, Chicago, IL, USA.

\section{Authors' contributions}

$V$ de $C-L$ and ADH conceived the study and, with SG, carried out the bioinformatic and function prediction work, and drafted the manuscript. RO and $A W$ participated in the bioinformatic analysis. BEY, MB, IKB, CH-B, LU, AL$N, A P$, and JCW performed the experimental validation experiments. $B E Y$ participated in manuscript preparation. All authors read and approved the final manuscript.

\section{Competing interests}

The authors declare that they have no competing interests.

Published: 15 June 2011

\section{References}

1. Bonneau R, Baliga NS, Deutsch EW, Shannon P, Hood L: Comprehensive de novo structure prediction in a systems-biology context for the archaea Halobacterium sp. NRC-1. Genome Biol 2004, 5:R52.

2. Siew N, Azaria Y, Fischer D: The ORFanage: an ORFan database. Nucleic Acids Res 2004, 32:D281-283.

3. Brenner SE: Errors in genome annotation. Trends Genet 1999, 15:132-133.

4. Devos D, Valencia A: Intrinsic errors in genome annotation. Trends Genet 2001, 17:429-431.

5. Tatusov RL, Koonin EV, Lipman DJ: A genomic perspective on protein families. Science 1997, 278:631-637.

6. Guigo R, Flicek P, Abril JF, Reymond A, Lagarde J, Denoeud F, Antonarakis $S$, Ashburner M, Bajic VB, Birney E, et al: EGASP: the human ENCODE Genome Annotation Assessment Project. Genome Biol 2006, 7(Suppl 1):S2.

7. Misra S, Crosby MA, Mungall CJ, Matthews BB, Campbell KS, Hradecky P, Huang Y, Kaminker JS, Millburn GH, Prochnik SE, et al: Annotation of the Drosophila melanogaster euchromatic genome: a systematic review. Genome Biol 2002, 3:RESEARCH0083.

8. Hanson AD, Pribat A, Waller JC, de Crécy-Lagard V: 'Unknown' proteins and 'orphan' enzymes: the missing half of the engineering parts list-and how to find it. Biochem J 2009, 425:1-11.

9. Schnoes AM, Brown SD, Dodevski I, Babbitt PC: Annotation error in public databases: misannotation of molecular function in enzyme superfamilies. PLoS Comput Biol 2009, 5:e1000605.

10. Overbeek R, Begley T, Butler RM, Choudhuri JV, Chuang HY, Cohoon M, de Crécy-Lagard V, Diaz N, Disz T, Edwards R, et al: The subsystems approach to genome annotation and its use in the project to annotate 1000 genomes. Nucleic Acids Res 2005, 33:5691-5702.

11. Vongsangnak W, Olsen P, Hansen K, Krogsgaard S, Nielsen J: Improved annotation through genome-scale metabolic modeling of Aspergillus oryzae. BMC Genomics 2008, 9:245.

12. Oberhardt MA, Palsson BO, Papin JA: Applications of genome-scale metabolic reconstructions. Mol Syst Biol 2009, 5:320

13. Saqi M, Dobson RJ, Kraben P, Hodgson DA, Wild DL: An approach to pathway reconstruction using whole genome metabolic models and sensitive sequence searching. J Integr Bioinform 2009, 6:107.

14. de Crécy-Lagard V, Hanson AD: Finding novel metabolic genes through plant-prokaryote phylogenomics. Trends Microbiol 2007, 15:563-570.

15. Haas B, Wortman J, Ronning C, Hannick L, Smith R, Maiti R, Chan A, Yu C, Farzad M, Wu D, et al: Complete reannotation of the Arabidopsis genome: methods, tools, protocols and the final release. BMC Biology 2005, 3:7.

16. Enright AJ, Van Dongen S, Ouzounis CA: An efficient algorithm for largescale detection of protein families. Nucleic Acids Res 2002, 30:1575-1584.

17. Haft DH, Selengut JD, White O: The TIGRFAMs database of protein families. Nucleic Acids Res 2003, 31:371-373.

18. Altschul SF, Madden TL, Schaffer AA, Zhang J, Zhang Z, Miller W, Lipman DJ: Gapped BLAST and PSI-BLAST: a new generation of protein database search programs. Nucleic Acids Res 1997, 25:3389-3402.

19. Koonin EV, Galperin MY: SEQUENCE-EVOLUTION-FUNCTION. Computational approaches in comparative genomics. Kluwer Academic Publishers; 2003.
20. Martin W, Rujan T, Richly E, Hansen A, Cornelsen S, Lins T, Leister D, Stoebe B, Hasegawa M, Penny D: From the Cover: Evolutionary analysis of Arabidopsis, cyanobacterial, and chloroplast genomes reveals plastid phylogeny and thousands of cyanobacterial genes in the nucleus. Proc Natl Acad Sci U S A 2002, 99:12246-12251.

21. Rhee SY, Beavis W, Berardini TZ, Chen G, Dixon D, Doyle A, GarciaHernandez M, Huala E, Lander G, Montoya M, et al: The Arabidopsis Information Resource (TAIR): a model organism database providing a centralized, curated gateway to Arabidopsis biology, research materials and community. Nucl Acids Res 2003, 31:224-228.

22. Horan K, Jang C, Bailey-Serres J, Mittler R, Shelton C, Harper JF, Zhu J-K, Cushman JC, Gollery M, Girke T: Annotating genes of known and unknown function by large-scale coexpression analysis. Plant Physiol 2008, 147:41-57.

23. Osterman A, Overbeek R, Rodionov D: The use of subsystems to encode biosynthesis of vitamins and cofactors. In Comprehensive Natural Products II Chemistry and Biology. Volume 7. Elsevier;Mander L, Lui H-W 2010:141-115.

24. Overbeek R, Fonstein M, D'Souza M, Pusch GD, Maltsev N: The use of gene clusters to infer functional coupling. Proc Natl Acad Sci U S A 1999, 96:2896-2901.

25. Huynen M, Snel B, Lathe W, Bork P: Predicting protein function by genomic context: quantitative evaluation and qualitative inferences. Genome Res 2000, 10:1204-1210.

26. Wolf $\mathrm{Yl}$, Rogozin IB, Kondrashov AS, Koonin EV: Genome alignment, evolution of prokaryotic genome organization, and prediction of gene function using genomic context. Genome Res 2001, 11:356-372.

27. Dandekar T, Snel B, Huynen M, Bork P: Conservation of gene order: A fingerprint of proteins that physically interact. Trends Biochem Sci 1998, 23:324-328.

28. Lee JM, Sonnhammer ELL: Genomic gene clustering analysis of pathways in Eukaryotes. Genome Res 2003, 13:875-882.

29. Lawrence JG, Roth JR: Selfish operons: horizontal transfer may drive the evolution of gene clusters. Genetics 1996, 143:1843-1860.

30. Yanai I, Mellor JC, DeLisi C: Identifying functional links between genes using conserved chromosomal proximity. Trends Genet 2002, 18:176.

31. Zimmermann P, Hirsch-Hoffmann M, Hennig L, Gruissem W: GENEVESTIGATOR. Arabidopsis microarray database and analysis toolbox. Plant Physiol 2004, 136:2621-2632.

32. Kopka J, Schauer N, Krueger S, Birkemeyer C, Usadel B, Bergmuller E, Dormann P, Weckwerth W, Gibon Y, Stitt M, et al: GMD@CSB.DB: the Golm Metabolome Database. Bioinformatics 2005, 21:1635-1638.

33. Toufighi K, Brady SM, Austin R, Ly E, Provart NJ: The Botany Array Resource: e-Northerns, expression angling, and promoter analyses. Plant J 2005, 43:153-163.

34. Friso G, Giacomelli L, Ytterberg AJ, Peltier J-B, Rudella A, Sun Q, van Wijk KJ: In-depth analysis of the thylakoid membrane proteome of Arabidopsis thaliana chloroplasts: new proteins, new functions, and a plastid proteome database. Plant Cell 2004, 16:478-499.

35. Heazlewood JL, Millar AH: AMPDB: the Arabidopsis Mitochondrial Protein Database. Nucleic Acids Res 2005, 33:D605-610.

36. Osterman A, Overbeek R: Missing genes in metabolic pathways: a comparative genomics approach. Curr Opin Chem Biol 2003, 7:238-251.

37. Kharchenko $P$, Chen L, Freund Y, Vitkup D, Church G: Identifying metabolic enzymes with multiple types of association evidence. BMC Bioinformatics 2006, 7:177.

38. Green ML, Karp PD: A Bayesian method for identifying missing enzymes in predicted metabolic pathway databases. BMC Bioinformatics 2004, 5:76.

39. Hyde JE, Dittrich S, Wang P, Sims PF, de Crécy-Lagard V, Hanson AD: Plasmodium falciparum: a paradigm for alternative folate biosynthesis in diverse microorganisms? Trends Parasitol 2008, 24:502-8.

40. Pribat A, Jeanguenin L, Lara-Nunez A, Ziemak MJ, Hyde JE, de CrécyLagard V, Hanson AD: 6-pyruvoyltetrahydropterin synthase paralogs replace the folate synthesis enzyme dihydroneopterin aldolase in diverse bacteria. J Bacteriol 2009, 191:4158-4165.

41. Conant GC, Wolfe KH: Turning a hobby into a job: how duplicated genes find new functions. Nat Rev Genet 2008, 9:938-950.

42. Haas CE, Rodionov DA, Kropat J, Malasarn D, Merchant SS, de CrécyLagard V: A subset of the diverse COG0523 family of putative metal chaperones is linked to zinc homeostasis in all kingdoms of life. BMC Genomics 2009, 10:470. 
43. Gabriel S, Helmann J: Contributions of Zur-controlled ribosomal proteins to growth under zinc starvation conditions. J Bacteriol 2009, 191:6116-6122.

44. Waller JC, Alvarez S, Naponelli V, Lara-Nunez A, Blaby IK, Da Silva V, Ziemak MJ, Vickers TJ, Beverley SM, Edison AS, et al: A role for tetrahydrofolates in the metabolism of iron-sulfur clusters in all domains of life. Proc Natl Acad Sci U S A 2010, 107:10412-10417.

45. Jeanguenin L, Lara-Nùñez A, Pribat A, Hamner Mageroy M, Gregory JF 3rd, Rice KC, de Crécy-Lagard V, Hanson AD: Moonlighting glutamate formiminotransferases can functionally replace 5 -formyltetrahydrofolate cycloligase. J Biol Chem 2010, 285:41557-66.

46. Hu P, Janga SC, Babu M, Diaz-Mejia JJ, Butland G, Yang W, Pogoutse O, Guo X, Phanse S, Wong P, et al: Global functional atlas of Escherichia coll encompassing previously uncharacterized proteins. PLOS Biol 2009, 7:e96

47. Chen $J-W$, Sun $C-M$, Sheng W-L, Wang Y-C, Syu W Jr.: Expression analysis of up-regulated genes responding to plumbagin in Escherichia coli. J Bacteriol 2006, 188:456-463.

48. Tomotake O, Masayuki H, Yoshiho I, Masayuki Se, Tsutomu S, Tsutomu K Jun-ichi K: Involvement of the Escherichia coli folate-binding protein YgfZ in RNA modification and regulation of chromosomal replication initiation. Mol Microbiol 2006, 59:265-275.

49. Gelling C, Dawes IW, Richhardt N, Lill R, Muhlenhoff U: Mitochondrial Iba57p is required for $\mathrm{Fe} / \mathrm{S}$ cluster formation on aconitase and activation of radical SAM enzymes. Mol Cell Biol 2008, 28:1851-1861.

50. Silverman M, Keresztesy JC, Koval GJ, Gardiner RC: Citrovorum factor and the synthesis of formylglutamic acid. J Biol Chem 1957, 226:83-94.

51. Bortoluzzi LC, MacKenzie RE: Glutamate formyl- and formiminotransferase activities from pig liver. Can J Biochem Cell Biol 1983, 61:248-253.

52. Goyer A, Collakova E, de la Garza RD, Quinlivan EP, Williamson J, Gregory JF, Shachar-Hill Y, Hanson AD: 5-Formyltetrahydrofolate is an inhibitory but well tolerated metabolite in Arabidopsis leaves. J Biol Chem 2005, 280:26137-26142.

53. Elkins BN, Keller EB: The enzymatic synthesis of N-(purin-6-ylcarbamoyl) threonine, an anticodon-adjacent base in transfer ribonucleic acid. Biochemistry 1974, 13:4622-4628.

54. Chheda GB, Hong Cl, Piskorz CF, Harmon GA: Biosynthesis of N-(purin-6ylcarbamoyl)-L-threonine riboside. Incorporation of L-threonine in vivo into modified nucleoside of transfer ribonucleic acid. Biochem J 1972, 127:515-519.

55. Powers DM, Peterkofsky A: Biosynthesis and specific labeling of N-(purin6-ylcarbamoyl)threonine of Escherichia coli transfer RNA. Biochem Biophys Res Commun 1972, 46:831.

56. Teplova M, Tereshko V, Sanishvili R, Joachimiak A, Bushueva T, Anderson WF, Egli $\mathrm{M}$ : The structure of the $y r d C$ gene product from Escherichia coli reveals a new fold and suggests a role in RNA binding. Protein Sci 2000, 9:2557-2566.

57. Kaczanowska M, Rydén-Aulin M: The YrdC protein-a putative ribosome maturation factor. Biochim Biophys Acta 2005, 1727:87.

58. Na JG, Pinto I, Hampsey M: Isolation and characterization of SUA5, a novel gene required for normal growth in Saccharomyces cerevisiae. Genetics 1992, 131:791-801.

59. Garcia GA, Goodenough-Lashua M: Mechanisms of RNA-Modifying and Editing Enzymes. In Modification and Editing of RNA. Washington, D.C.: ASM Press;Grosjean H, Benne R 1998:135-168.

60. El Yacoubi B, Lyons B, Cruz Y, Reddy R, Nordin B, Agnelli F, Williamson JR, Schimmel P, Swairjo MA, de Crécy-Lagard V: The universal YrdC/Sua5 family is required for the formation of threonylcarbamoyladenosine in tRNA. Nucleic Acids Res 2009, 37:2894-2909.

61. Aziz R, Bartels D, Best A, DeJongh M, Disz T, Edwards R, Formsma K, Gerdes S, Glass E, Kubal M, et al: The RAST server: rapid annotations using subsystems technology. BMC Genomics 2008, 9:75.

62. Lee I, Ambaru B, Thakkar P, Marcotte EM, Rhee SY: Rational association of genes with traits using a genome-scale gene network for Arabidopsis thaliana. Nat Biotechnol 2010, 28:149-156.

63. Lee $D$, Redfern $O$, Orengo $C$ : Predicting protein function from sequence and structure. Nat Rev Mol Cell Biol 2007, 8:995-1005.

64. Jung KH, Dardick C, Bartley LE, Cao P, Phetsom J, Canlas P, Seo YS, Shultz M, Ouyang S, Yuan $Q$, et al: Refinement of light-responsive transcript lists using rice oligonucleotide arrays: evaluation of generedundancy. PLoS One 2008, 3:e3337.
65. Ogata Y, Suzuki H, Shibata D: A database for poplar gene co-expression analysis for systematic understanding of biological processes, including stress responses. J Wood Sci 2009, 55:395-400.

66. Larmande P, Gay C, Lorieux M, Perin C, Bouniol M, Droc G, Sallaud C, Perez P, Barnola I, Biderre-Petit C, et al: Oryza Tag Line, a phenotypic mutant database for the Genoplante rice insertion line library. Nucleic Acids Res 2008, 36:D1022-1027.

67. Larkin MA, Blackshields G, Brown NP, Chenna R, McGettigan PA, McWilliam $H$, Valentin F, Wallace IM, Wilm A, Lopez $R$, et al: Clustal W and Clustal X version 2.0. Bioinformatics 2007, 23:2947-2948.

68. Thompson JD, Gibson TJ, Higgins DG: Multiple sequence alignment using ClustalW and ClustalX. Curr Protoc Bioinformatics 2002, Chapter 2: Unit 23.

69. Kanehisa M, Goto S: KEGG: kyoto encyclopedia of genes and genomes. Nucleic Acids Res 2000, 28:27-30.

70. Schomburg I, Chang A, Schomburg D: BRENDA, enzyme data and metabolic information. Nucleic Acids Res 2002, 30:47-49.

71. Kelley LA, Sternberg MJE: Protein structure prediction on the Web: a case study using the Phyre server. Nat Protoc 2009, 4:363-371.

72. Finn RD, Mistry J, Tate J, Coggill P, Heger A, Pollington JE, Gavin OL, Gunasekaran P, Ceric G, Forslund K, et al: The Pfam protein families database. Nucleic Acids Res 2010, 38:D211-222.

73. Alm EJ, Huang KH, Price MN, Koche RP, Keller K, Dubchak IL, Arkin AP: The MicrobesOnline Web site for comparative genomics. Genome Res 2005, 15:1015-1022

74. Rudd KE: EcoGene: a genome sequence database for Escherichia coli K12. Nucleic Acids Res 2000, 28:60-64

75. Keseler IM, Bonavides-Martinez C, Collado-Vides J, Gama-Castro S, Gunsalus RP, Johnson DA, Krummenacker M, Nolan LM, Paley S, Paulsen IT, et al: EcoCyc: a comprehensive view of Escherichia coli biology. Nucleic Acids Res 2009, 37:D464-470.

76. Nakao M, Okamoto S, Kohara M, Fujishiro T, Fujisawa T, Sato S, Tabata S, Kaneko T, Nakamura Y: CyanoBase: the cyanobacteria genome database update 2010. Nucleic Acids Res 2010, 38:D379-D381.

77. Winsor GL, Van Rossum T, Lo R, Khaira B, Whiteside MD, Hancock RE, Brinkman FS: Pseudomonas Genome Database: facilitating user-friendly, comprehensive comparisons of microbial genomes. Nucleic Acids Res 2009, 37:D483-488

78. Obayashi T, Hayashi S, Saeki M, Ohta H, Kinoshita K: ATTED-II provides coexpressed gene networks for Arabidopsis. Nucleic Acids Res 2009, 37 D987-991.

79. Sun Q, Zybailov B, Majeran W, Friso G, Olinares PD, van Wijk KJ: PPDB, the Plant Proteomics Database at Cornell. Nucleic Acids Res 2009, 37:D969-974

80. Berman H, Henrick K, Nakamura H, Markley JL: The worldwide Protein Data Bank (wwPDB): ensuring a single, uniform archive of PDB data. Nucleic Acids Res 2007, 35:D301-303.

81. Naponelli V, Noiriel A, Ziemak MJ, Beverley SM, Lye LF, Plume AM, Botella JR, Loizeau K, Ravanel S, Rebeille F, et al: Phylogenomic and functional analysis of pterin-4a-carbinolamine dehydratase family (COG2154) proteins in plants and microorganisms. Plant Physiol 2008, 146:1515-1527.

82. El Yacoubi B, Hatin I, Deutsch C, Kahveci T, Rousset J-P, Iwata-Reuyl D, G Murzin A, de Crécy Lagard V: A role for the universal Kae1/Qri7/YgjD (COG0533) family in tRNA modification. EMBO J 2011, 30:882-893.

83. Engqvist M, Drincovich MF, Flugge UI, Maurino VG: Two D-2-hydroxy-acid dehydrogenases in Arabidopsis thaliana with catalytic capacities to participate in the last reactions of the methylglyoxal and beta-oxidation pathways. J Biol Chem 2009, 284:25026-25037.

84. Kimura S, Suzuki T: Fine-tuning of the ribosomal decoding center by conserved methyl-modifications in the Escherichia coli 16S rRNA. Nucleic Acids Res 2010, 38:1341-1352.

85. Chigri F, Sippel C, Kolb M, Vothknecht UC: Arabidopsis OBG-like GTPase (AtOBGL) is localized in chloroplasts and has an essential function in embryo development. Mol Plant 2009, 2:1373-1383.

86. Preumont A, Snoussi K, Stroobant V, Collet JF, Van Schaftingen E: Molecular identification of pseudouridine-metabolizing enzymes. J Biol Chem 2008, 283:25238-25246.

87. Komatsu T, Kawaide H, Saito C, Yamagami A, Shimada S, Nakazawa M, Matsui M, Nakano A, Tsujimoto M, Natsume M, et al: The chloroplast protein BPG2 functions in brassinosteroid-mediated post-transcriptional accumulation of chloroplast rRNA. Plant J 2010, 61:409-422. 
88. Sudhamsu J, Lee Gl, Klessig DF, Crane BR: The structure of YqeH. An AtNOS1/AtNOA1 ortholog that couples GTP hydrolysis to molecular recognition. J Biol Chem 2008, 283:32968-32976.

89. Schwenkert S, Netz DJ, Frazzon J, Pierik AJ, Bill E, Gross J, Lill R, Meurer J: Chloroplast HCF101 is a scaffold protein for [4Fe-4S] cluster assembly. Biochem J 2009, 425:207-214.

90. Hausmann A, Aguilar Netz DJ, Balk J, Pierik AJ, Muhlenhoff U, Lill R: The eukaryotic P loop NTPase Nbp35: an essential component of the cytosolic and nuclear iron-sulfur protein assembly machinery. Proc Natl Acad Sci U S A 2005, 102:3266-3271.

91. Wurm JP, Meyer B, Bahr U, Held M, Frolow O, Kotter P, Engels JW, Heckel A Karas $\mathrm{M}$, Entian KD, et al: The ribosome assembly factor Nep1 responsible for Bowen-Conradi syndrome is a pseudouridine-N1-specific methyltransferase. Nucleic Acids Res 2010, 38:2387-2398.

92. Jaisson S, Veiga-da-Cunha M, Van Schaftingen E: Molecular identification of omega-amidase, the enzyme that is functionally coupled with glutamine transaminases, as the putative tumor suppressor Nit2. Biochimie 2009, 91:1066-1071.

93. Krasnikov BF, Chien CH, Nostramo R, Pinto JT, Nieves E, Callaway M, Sun J, Huebner $\mathrm{K}$, Cooper AJ: Identification of the putative tumor suppressor Nit2 as omega-amidase, an enzyme metabolically linked to glutamine and asparagine transamination. Biochimie 2009, 91:1072-1080.

94. Teplyakov A, Obmolova G, Sarikaya E, Pullalarevu S, Krajewski W, Galkin A, Howard AJ, Herzberg O, Gilliland GL: Crystal Structure of the YgfZ Protein from Escherichia coli Suggests a folate-dependent regulatory role in onecarbon metabolism. J Bacteriol 2004, 186:7134-7140.

95. Guzman LM, Belin D, Carson MJ, Beckwith J: Tight regulation, modulation, and high-level expression by vectors containing the arabinose $\mathrm{P}_{\mathrm{BAD}}$ promoter. J Bacteriol 1995, 177:4121-4130.

96. Da Re S, Le Quere B, Ghigo J-M, Beloin C: Tight modulation of Escherichia coli bacterial biofilm formation through controlled expression of adhesion factors. Appl Environ Microbiol 2007, 73:3391-3403.

doi:10.1186/1471-2164-12-S1-S2

Cite this article as: Gerdes et al: Synergistic use of plant-prokaryote comparative genomics for functional annotations. BMC Genomics 2011 12(Suppl 1):S2.

\section{Submit your next manuscript to BioMed Central and take full advantage of:}

- Convenient online submission

- Thorough peer review

- No space constraints or color figure charges

- Immediate publication on acceptance

- Inclusion in PubMed, CAS, Scopus and Google Scholar

- Research which is freely available for redistribution 